\title{
Syphilis Notification Systems in Korea over the Last 20 Years
}

\author{
Yumi Seo, Gilho Lee \\ Department of Urology, Dankook University College of Medicine, Cheonan, Korea
}

Purpose: The syphilis notification system has been revised three times in Korea during the last 20 years. Accordingly, we evaluated the performance of the three systems by analyzing data from the Korea Disease Control and Prevention Agency (KDCA).

Materials and Methods: We analyzed trends of stage 1, 2, and congenital syphilis cases reported in the KDCA from 2001 to 2010 in the 1st sentinel (S1), from 2011 to 2019 in the 1st universal (U1), and 2020 in the 2nd sentinel (S2) notification system.

Results: A total of 21,820 syphilis cases were reported, 9,177 cases in S1, 12,321 in $\mathrm{U} 1$, and 322 in S2, respectively. The reported cases can be presented in the form of four expanding waves across the time period. Although the most commonly reported age group with infection was 20-29 years in all three reporting systems, the pattern of infections was different; the number of older patients was relatively high in the S1 group while the number of syphilis cases declined sharply in the older than 20-29 old age group in the U1 and S2 systems. Also, there was a sex-based difference in the three groups; the data from S1 were female-dominant but the data in U1 and S2 were male-dominant.

Conclusions: Our results showed that the universal notification system (U1) is superior in both the quantity and quality of data to the previous sentinel system (S1). The results from the new system, S2, are similar to those from U1.

Keywords: Syphilis; Surveillance; Trend; Korea

Copyright (c) 2021, Korean Association of Urogenital Tract Infection and Inflammation. All rights reserved. (1) (\$) This is an open access article distributed under the terms of the Creative Commons Attribution Non-Commercial License (http://creativecommons.org/licenses/by-nc/4.0) which permits unrestricted non-commercial use, distribution, and reproduction in any medium, provided the original work is properly cited.
Received: 31 March, 2021

Revised: 14 April, 2021

Accepted: 14 April, 2021

\author{
Correspondence to: Gilho Lee \\ (iD https://orcid.org/0000-0002-9253-6245 \\ Department of Urology, Dankook University College \\ of Medicine, 119 Dandae-ro, Dongnam-gu, Cheonan \\ 31116, Korea \\ Tel: +82-41-550-6630, Fax: +82-41-550-3905 \\ E-mail: tothisway@naver.com
}

\section{서론}

최근 우리나라뿐만 아니라 전 세계적으로 유행하는 코로나19 감염 사례로 보듯이 감염병으로 야기되는 사회적 혼란을 고려해 국가는 국민의 안전을 위해 효율적인 감염병 관리 대책을 구축해야 한다[1-5]. 이에 사용되는 감염병 감시체계 는 항상 일정할 수는 없고, 새로운 감염병 발생, 기존 감염병 소실, 새로운 진단법 개발 등을 고려해 첨가, 수정, 삭제 등을 통해 지속적으로 갱신해야 한다[2-4]. 그러나 빈발한 감시체 계 변경은 이전 체계 자료의 이용에 한계점이 있어 감염병
동향이나 추세를 파악할 수 없다는 단점이 있다. 따라서 갱신된 감시체계는 기존의 감시체계와 비교해 장점 및 단점을 파악하 고, 이를 유지, 보완할지 아니면 이전 체계로 돌아갈지 결정해 야 한다.

감염병 감시체계는 보고체계에 따라 모든 의료인이 감염 환자를 보고해야 하는 전수감시체계(universal surveillance) 와 일부 대표성을 가진 표본감시기관으로 지정된 의료기관이 나 의료인이 보고하는 표본감시체계(sentinel surveillance) 가 있다. 특정 감염병을 전수감시로 할지 혹은 표본감시로 할지는 질병 특징, 공공보건 위협, 의료인 역량, 사회경제학적 
인 요인 등과 같은 많은 인자에 의해 결정된다[2-5].

우리나라에서 환자 진단 시 보건당국에 보고하도록 지정된 성매개감염병은 후천성면역결핍증, 매독, 임질, 클라미디아 감염증, 성기 단순포진, 첨규콘딜롬, 연성하감 등이 있다. 이러 한 감염병은 성교를 통해 전파되고, 남성 혹은 여성 생식기에 병변이 발생하여 외부에 드러나지 않고, 환자 자신의 낙인 효과로 의료기관에 방문하지 않아 국가 감시에 잘 노출되지 않으며, 은밀하게 전파되는 것을 특징으로 한다[2,6].

트레포네마 매독균(Treponema pallidum) 감염으로 발 생하는 매독은 생식기 및 전신증상을 특징으로 하는데, 균이 침입하고 평균 1 달의 잠복기를 거친 후 균이 침입하는 남녀 생식기에 발생하는 경성하감(chancre)이 발생하는 1 기 매독 의 특징적인 생식기 병변이 있다. 이 병변은 치료하지 않아도 감염 6주에서 6개월 이내에 사라지지만, 매독균의 전신 침투 로 전신에 발생하는 다양한 피부 병변을 보이는 2 기 매독에 이르게 된다. 또한 매독은 태내 감염을 유발해 태아에게 선천성 매독(congenital syphilis)을 발생시켜, 사산되거나 기형아 로 출생하기도 한다[7].

우리나라 질병관리청은 이러한 은밀하고 전파력이 높은 매독, 즉 1 기, 2 기 및 모자보건 평가인자인 선천성 매독에 대해 2010년까지 표본감시체계로 그 발생을 감시하였고, 2011년부터 새로운 감시체계 아래에 매독을 전수조사체계 대상으로 변경하였으나 9년이 지난 2020년부터 매독은 다시 표본조사체계로 변경되었다[4,8].

감염병의 올바른 감시체계를 위해서는 양적으로는 통계분 석이 가능할 정도로 많은 보고 건수, 질적으로는 정확한 자료 보고가 중요하다. 양적인 척도는 정보의 총량을 지칭하는 것으 로 비교적 정의가 쉽지만, 질적으로 좋은 정보란 정확한 정보를 의미하지만, 그 정의가 쉽지 않다[9]. 이러한 이유로 좋은 정보란 기존에 발표되었고 그 결과가 공식적으로나 학문적으 로 인정된 결과, 혹은 그 정보의 중요성이 인정된 결과로 정의 할 수 있지만, 기존의 틀을 파괴할 정도로 특이한 감염이 발생 하면 그 원칙을 지킬 수는 없다. 또한, 질적인 척도가 보장되지 않는 다량의 정보, 즉 여과되지 않고 수동적으로 보고된 포괄적 인 자료는 감염병에 대해 잘못된 판단을 내리게 할 수도 있다 $[2,5,8]$.

저자는 빈번하게 개정된 우리나라 매독에 대한 감시체계, 즉 2010년까지 시행된 1차 표본감시체계, 2011-2019년도 까지의 1 차 전수감시체계, 2020년 되돌아간 2차 표본감시체 계를 통해 대한민국 질병관리청에 보고된 지난 20년 치 매독 환자 자료를 분석하여, 시행되어 왔던 우리나라의 매독 감시체 계 운영 및 시행의 문제점을 체계적으로 분석하고, 이 결과를 토대로 2020년 새롭게 개정된 표본감시체계를 평가하고자 한다. 또한 20년 동안 축적된 매독 정보 중 우리나라 질병관리 청 포털, 포털 자료를 검증하기 위해 질병관리청에 요청해
받은 자료, 건강보험심사평가원 자료, 일본 후생성 포털 자료 등을 분석해 우리나라 매독 환자 추이를 분석하였다.

\section{대상 및 방법}

\section{1. 자료 수집 및 윤리적 고려}

연구에 사용된 매독 환자 자료는 대한민국 질병관리청 홈페 이지에 등록된 개방 자료(http://www.kdca.go.kr), 일본 후생성에 보고된 일본 개방 자료(https://www.mhlw.go.jp), 2001년도부터 2016년도까지 질병관리청에 보고된 매독 환 자 자료 중 코드화된 의료기관을 포함한 세부 자료 및 대한민국 건강보험심사평가원(https://opendata.hira.or.kr/home.do) 자료를 받아 분석하였다. 본 연구는 연구자 소속기관의 연구윤 리위원회로부터 연구 승인(IRB No. 2016-09-014)을 받았 으며, 모든 자료에서 환자를 식별하거나 추적 가능한 자료는 없었다.

\section{2. 자료}

\section{1) 대한민국 질병관리청 자료 분석}

2001년도부터 2020년까지 매독 보고 의무를 가진 각 의료기관으로부터 지역 보건소를 통해 질병관리청으로 보고 된 1 기, 2 기, 선천성 매독 환자 자료를 질병관리청 감염병 포털 혹은 2019년도 감염병 감시연보 자료를 통해 분석하였다 [10,11]. 자료에 포함된 변수는 보고 연도, 지역, 성별, 계층화 된 나이별 보고 건수 등이 있었다. 공개된 자료 검토 및 통계 분석을 위해 2001년도부터 2016년도 9월까지 개별 매독 환자를 보고한 무기명 처리된 의료기관 코드와 연도별 - 기관 별 보고 건수, 성별, 나이별 자료를 질병관리청으로부터 제공 받아 분석하였다.

\section{2) 대한민국 건강보험심사평가원 자료 분석}

2008년도부터 2014년도까지 대한민국 건강보험심사평가 원에 청구된 매독 환자 중 연도별 1 기, 2 기, 선천성 매독 환자 자료를 제공받아 분석하였다.

\section{3) 일본 자료 분석}

2000년도부터 2019년까지 전수감시를 통해 일본 각 의료 기관으로부터 일본 후생성으로 보고된 자료 중에 1 기, 2 기, 선천성 매독, 무증상 매독 환자 자료를 일본 후생성 포털에서 구해 분석하였다[12]. 자료에 포함된 변수는 보고 연도, 성별, 계층화된 나이 등이 있었다.

\section{3. 분석}

전수감시체계와 표본감시체계를 통해 보고된 정보의 질을 판단하기 위해 성별에 대해서는 카이제곱 검정, 나이에 대해서 
는 $\mathrm{t}$-검정을 시행하였다. 모든 분석은 IBM SPSS for Windows ver. 23 (IBM Corp., Armonk, NY, USA) 프로그 램을 사용하였으며, 유의 수준은 0.05 미만으로 하였다.

\section{결과}

\section{1. 대한민국 질병관리청 자료 분석: 기간 혹은 보고 체계에 따른 매독 환자 수 및 성별 변화}

2001년부터 2010년까지 시행된 1차 표본감시체계의 결과 에 따르면 남자는 매년 평균 405명(중위수: 439명), 여자는 513명(중위수: 536명)으로 총 918명(중위수: 976명)이 보고 되었으며, 남자보다는 여자가 많이 보고되었다. 2011년도부 터 2019년까지 시행된 1차 전수감시체계 자료에 따르면 남자 는 매년 평균 884명(중위수: 601명), 여자 485명(중위수: 475명), 총 1,369명(중위수: 1,015명)이 보고되었다. 여자보 다 남자가 많이 보고되었다.

2003년까지는 남자가 여자보다 많이 보고되었으나, 2004 부터 2010년까지 여자가 더 많이 보고되었다. 2011년-2012 년도에 성비 교차가 발생하였고, 그 간격은 2019년까지 점차 커짐을 알 수 있었다(Fig. 1). 보고 환자는 2001년부터 점차적 인 증가 및 일시적인 감소를 보이다가, 2008년에 1차 정점을 찍고 2012년도까지 감소하다가 2013년도부터 다시 증가해, 2018년도 2차 정점에 도달하였다. 특이하게 2016년도부터 남성 환자의 발생이 급격하게 증가하다가 2018년도 정점에 도달하였으며, 그 다음 해인 2019년도에는 감소하였다(Fig. 1).

2001년도부터 2016년도 9월까지 질병관리청 감시과를 통해 수집된 14,949건의 개별 자료 분석에 의하면 1차 표본감 시체계 10년 동안(2001년-2010년) 수집한 자료는 총 9,177 건으로 이 중 남자는 4,050 건, 여자는 5,127 건이었으며, 전수 감시체계가 이루어진 6년 동안(2011년-2016년 9월까지 자 료) 수집한 자료는 5,772건으로 남자는 3,246건, 여자는
2,526건으로 표본감시체계보다 전수감시체계에서 남자가 여 자보다 통계학적으로 유의하게 높게 보고되었다( $\mathrm{p}=0.001)$.

\section{2. 대한민국 질병관리청 자료 분석: 기간 혹은 보고 체계에 따른 환자 연령 분포 분석}

2001년-2010년도 1차 표본감시체계 결과나 2011년-2019 년도 1차 전수감시체계 결과에 따르면 동일하게 20-29세에 매독이 가장 빈발하게 보고되었다. 또한 두 보고체계 모두 시간이 지나감에 따라, 즉 감시체계가 안정됨에 따라 20-29세 의 빈도수 증가가 도드라졌다(Fig. 2).

전수감시체계를 통해 얻은 2011년-2015년도까지 5년 각 각의 연령분포는 서로 비슷해 한 개의 군집을 이루고, 2016년 도-2019년도까지 4개년도 연령분포는 또 다른 하나의 군집을 이루는데, 이는 20-29세 환자 발생이 2016년도부터 급격히 증가해 2017년과, 2018년을 거쳐 정점을 찍은 후 2019년도 에 감소하는 특징을 보여주고 있다. 또한 1차 표본감시체계와 1 차 전수감시체계의 확연한 차이는 40-49, 50-59 연령대에 서 관찰할 수 있는데, 1 차 표본감시의 결과는 1 차 전수감시의 결과에 비교해 장년층에서 상대적으로 높은 발생 빈도를 보여 주었다(Fig. 2).

질병관리청 질병감시과로부터 제공받은 개별 자료 분석에 의하면, 1 차 표본감시체계 10 년 동안 보고된 환자의 평균 나이는 $36.83 \pm 13.34$ 세였으며, 1 차 전수감시체계가 이루어 진 6년 동안 보고된 환자의 평균 나이는 $33.71 \pm 14.64$ 세로 1 차 전수감시 기간의 환자가 1 차 표본감시 기간보다 젊었다 $(\mathrm{p}=0.001)$.

\section{3. 대한민국 질병관리청 자료 분석: 2 차 표본조사체계 자료 분석}

2020년도부터 시행된 2차 표본감시체계에는 선천성 매독 3 예를 포함해 남자 222명, 여자 100 명, 총 322 명이었다. 2 차 표본감시체계에 의거한 환자의 연령 분포 및 성별은 1 차

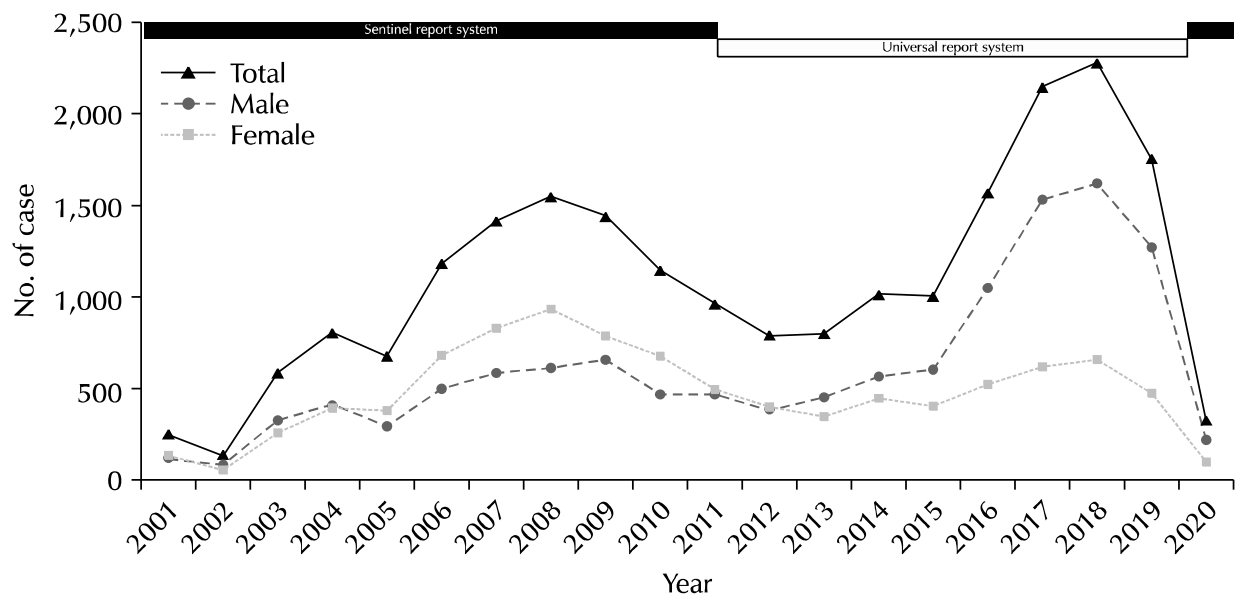

Fig. 1. The reported cases of primary syphilis, secondary syphilis, and congenital syphilis from the Korea Disease Control and Prevention Agency data between 2001 and 2020. Female dominance was reversed from 2013. The first sentinel surveillance system for syphilis was implemented from 2001 to 2010 , the first universal surveillance system was from 2011 to 2019, and the second sentinel surveillance from 2020. 
표본감시체계 때보다 1차 전수감시체계의 결과와 일치하는 경향을 보인다(Fig. 1, 3).

\section{4. 대한민국 건강보험심사평가원 자료 분석}

우리나라 건강보험심사평가원 자료에 따르면 1 기, 2기, 선천성 매독은 2008년도 38,205명, 2009년도 37,467명, 2010년도 34,554명, 2011년도 35,544명, 2012년도 36,242명, 2013년도 34,824명, 2014년도는 36,265명이 보고되었다.

\section{5. 일본 후생성 자료 분석}

2000년도부터 2019년까지 20년 동안 전수감시체계로 보 고된 매독 환자 자료를 분석해 보면 연평균 총 1,916 명(중위 수: 793명) 중 남자는 1,338 명(중위수: 569 명), 여자는 평균 578명(중위수: 197명)으로 남자가 많았다. 연령분포를 보면 20-29세에 최다 빈도를 보이다가 보고 빈도는 점차 감소하였 다. 2000년도부터 2012년도까지 비슷한 분포를 보이다가 2013년-2014년도에 20-29세와 30-39세에서 증가를 보이 고, 2015년도에는 20-29세에서 뚜렷한 증가 경향을 보이다 2016년-2017년도를 거쳐 2018년도에 정점을 찍고, 2019년 도에는 그 빈도수가 감소하였다(Fig. 4).

\section{고찰}

감시체계를 담당하는 공공기관이 능동적으로 관여하는 능 동적 감시체계는 국가 내 모든 의료기관으로부터 감염병 환자 발생을 정해진 기간 내 즉시 보고받고, 그 보고를 확인 및 판단, 그리고 다시 일선 의료기관으로 빠른 결정을 제공하는

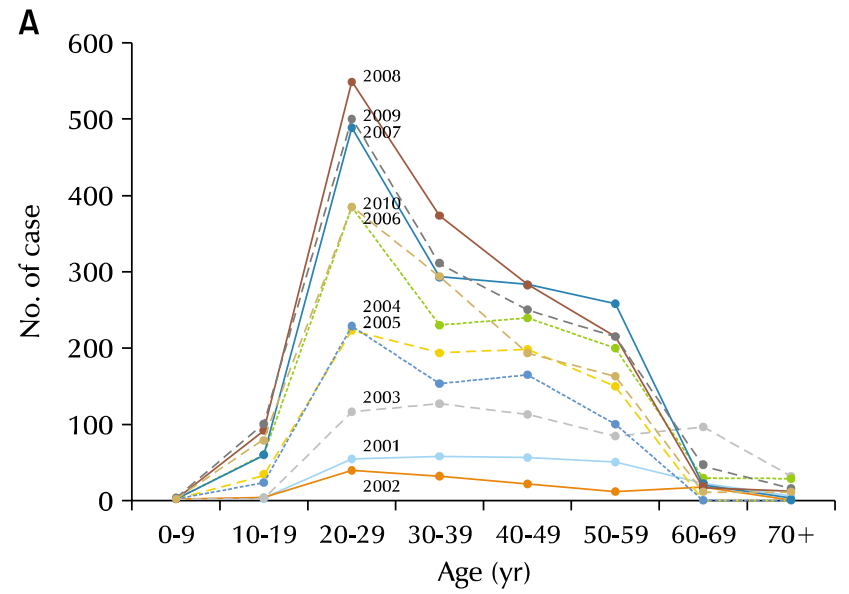

것이 특징이다. 코로나-19 감염병과 같이 공공의료에 치명적 인 문제점을 야기하는 감염병이 대상에 포함될 수 있다. 이는 이상적인 감시체계이지만 국가의 지속적이고 능동적인 감시는 관계자들의 피로도를 급증시킬 수 있고, 체계 구축 및 유지를 위해 국가의 막대한 예산이 투입되는 단점이 있다. 이에 반해, 수동적 전수감시체계란 감시 주체는 모든 의료기관으로, 전 의료기관이 특정 감염병 정보를 제시된 기간 내에 국가기관에 보고하는 형태이다. 자료의 양은 충분할 수 있으나, 관련 의료 인 교육이 잘 이루어지지 않는 의료관계자가 보고하여 확실하 지 않는 자료가 수집, 보고될 수 있다. 장점은 능동적 전수감시 체계에 비해 비용이 적게 들어 경제적이지만, 단점으로는 보고 자료의 질이 낮아 자료 분석에 한계점이 있다[2-9,13-15].

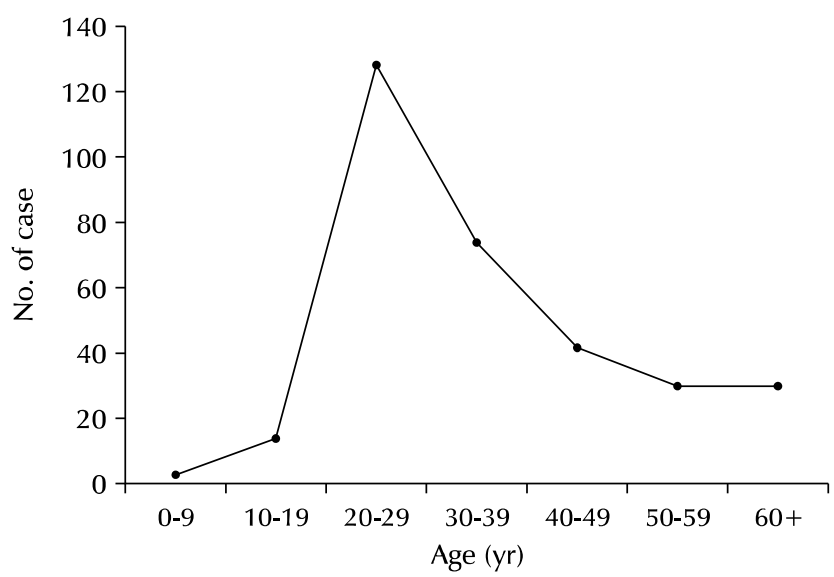

Fig. 3. Reported syphilis cases in 2020 by age intervals. The Korea Disease Control and Prevention Agency has revised the reporting system for syphilis from the universal surveillance system to the sentinel surveillance system.

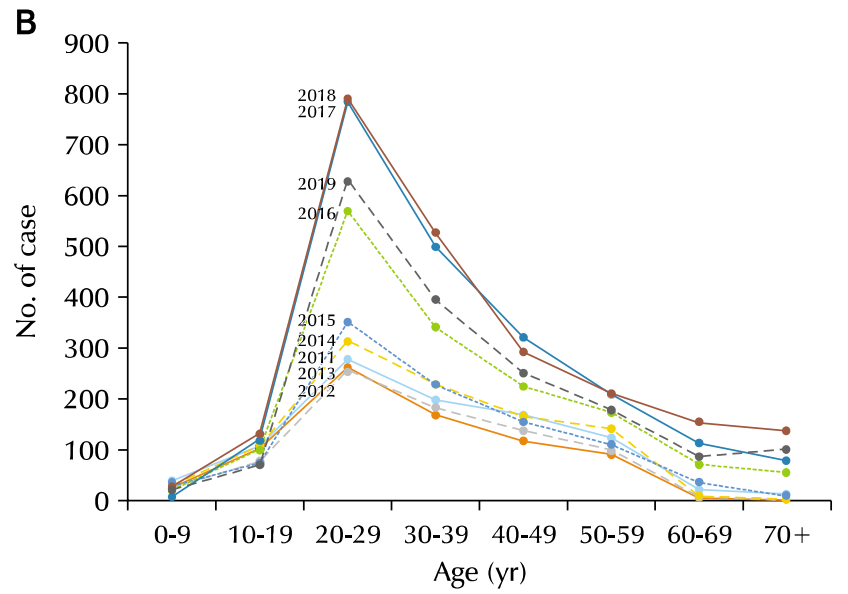

Fig. 2. The distribution of reported syphilis cases from the Korea Disease Control and Prevention Agency dataset by age intervals. (A) Age distributions during the first sentinel surveillance system for syphilis from 2001 to 2010 . Based on the first sentinel surveillance system, the number of syphilis cases was highest in the 20-29-year age group and the number of cases decreased slowly in older age groups. (B) Age distributions during the first universal surveillance system from 2011 to 2019 revealed a single peak in 20-29-year-olds like the cases in the first sentinel surveillance system, followed by a sharp decrement in later ages (40-49 years, $50-59$ years). 


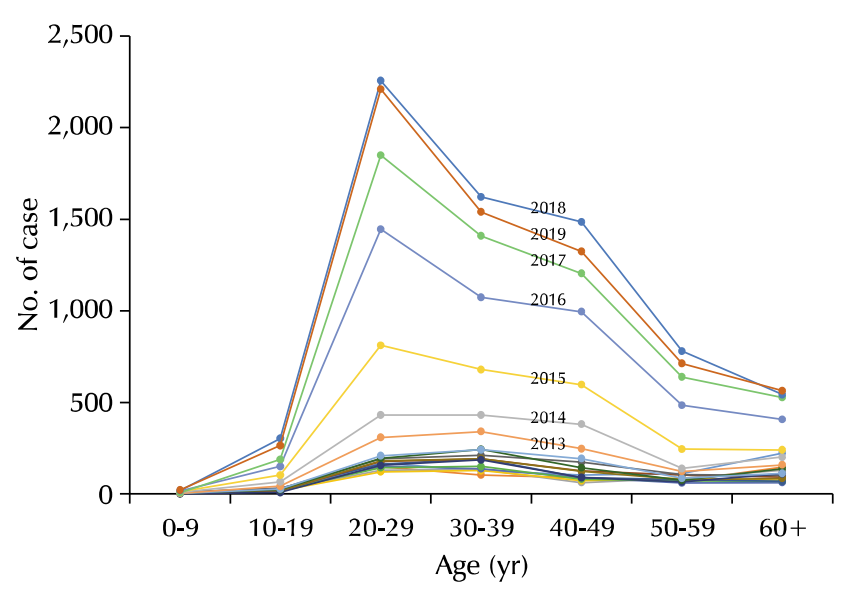

Fig. 4. Notified cases of primary syphilis, secondary syphilis, congenital syphilis, and asymptomatic syphilis by age intervals from 2000 to 2019 in Japan. Data were obtained from the Japanese Ministry of Health, Labour and Welfare (https://www.mhlw.go.jp/topics/2005/04/tp04111. html).

표본감시체계는 특정 질환 감시에 대표성이 있는 의료기관 을 국가가 지정해 특정 감염병 정보를 보고하는 시스템이다. 이 중 능동적 표본감시체계란 국가나 보건당국이 지정된 의료 기관에 대한 적절한 교육, 인센티브 및 지원, 진단법의 표준화 등에 관여하는 것으로 이상적으로 운영된다면, 능동적 전수감 시체계와 유사한 결과를 얻을 수 있어, 이는 의료 인프라가 잘 갖춰진 국가에 적용할 수 있는 비용 대비 이상적인 보고 체계라 생각할 수 있다. 그러나 수동적 표본감시체계와 같이 국가의 관심이나 지원이 없고 단순히 지정된 의료기관의 보고 만 수집한다면 한정된 의료기관의 확실하지 않는 자료가 수집 되어 국가 감염병 보고 및 감시체계의 근간이 흔들리게 된다 [2-9,13-15].

우리나라 질병관리청은 법정감염병 감시체계를 개정해 2011년도부터 매독은 과거 표본감시체계에서 전수감시체계 로 변경하고 효율적인 보고를 위해 과거에 시행돼 왔던 모사전 송(FAX) 또는 컴퓨터 통신 등을 통한 방법 외에 질병관리청 인터넷 홈페이지를 통한 보고 방법이 추가되었다[4,9]. 또한 보고체계의 관리 유지를 위해 의료기관에서 보고된 자료를 일선 보건소나 질병관리청 소관부서에서 검토 후 의심되는 자료의 재확인 과정을 거치는 일부 능동성 감시체계를 도입하 였다[9,16]. 10년이 지난 2019년도에 감염병 예방 및 관리에 관한 법률 개정에 따른 성매개감염병 신고 기준 변경에 따라 우리나라 질병관리청은 감염병 분류를 새롭게 하고 매독의 경우 기존의 3군 감염병의 전수감시체계에서 2020년부터는 4 급 감염증의 표본감시체계로 재분류하였다[8].

한 국가 내 감염병 감시체계는 시간이 지나감에 따라 개정이 불가피하다. 하지만 빈번한 감시체계 변경은 이전 체계의 자료 를 기반으로 한 질병의 동향이나 추세를 파악할 수 없다는 큰 단점이 있다. 일본의 경우 1999 년부터 개정된 전수 매독
감시체계가 20년 이상 지속된 점, 그리고 미국의 경우도 수동 적 감시체계로 성매개감염병 감시를 장시간 유지한 점을 고려 한다면 감시체계의 유지나 개정에 대한 분명한 장단점이 있을 것으로 생각한다[3,12,15]. 또한 감시체계가 개정되었다면 이전 체계의 자료와 비교해 감염병의 특징이 서로 일치하는가 를 확인하는 것이 중요하며, 결과를 충분하게 검토한 후 새로운 체계로 유지하고 보완할지 아니면 이전 체계로 돌아갈지 결정 해야 한다.

매독은 의학 역사나 감염병 역사에 많은 영향을 주었고, 특효약인 페니실린이 개발된 후에도 여전히 인류의 건강한 삶을 위협하고 있으며, 최근 후천성면역결핍증 발생에도 관여 한다고 알려지고 있다[7,17]. 매독은 특징적 임상 경과에 따라 증상이 있는 1 기 및 2 기, 그리고 감염 후 1 년 이내의 시기로 증상은 없지만 감염성이 있는 조기 잠복매독 등의 조기 매독과, 1 년 후 후기 잠복매독 혹은 3 기 매독으로 구분할 수 있다 [7,17]. 선천성 매독은 대개 임신 4 개월 후에 감염이 발생하여 모자보건에 심각한 영향을 미친다. 최근 미국에서 매독에 의한 태아 사산이 증가해, 2018년도 미국질병관리본부에서는 선천 성 매독에 의한 태아 사산에 관해 의료진의 관심을 촉구하였다 $[7,15,17,18]$.

매독의 검사실 검사로는 비매독항원시험법과 매독항원시험 법이 있는데 항원검사법인 treponema pallidum hemagglutination assay와 fluorescent treponemal antibody absorption으로 확진한다[19]. 매독 감시체계에서 매독검사 법이 중요한 이유는 과거에는 1 차 의료기관이나 비전문가들에 의해 비매독항원시험법을 통한 매독 진단이 빈발하게 이루어 졌으며, 이러한 결과를 국가 감시체계에 보고하기도 하였다 [9]. 이에 반해 일본의 경우 증상이 있는 1 기, 2 기, 선천성 매독뿐만 아니라 무증상 병원체 보유자, 매독으로 인해 사망한 환자도 감시체계에 포함해 우리나라보다는 더 포괄적인 감시 체계를 유지하였다[12].

2001년도부터 2010년까지 시행된 1차 표본감시체계에 따른 결과와 2011년도부터 2019년도까지 시행된 1차 전수감 시체계의 결과와 비교하면, 일부 대표 의료기관이 참여해서 보고하는 표본감시체계 하의 환자 수가 전 의료기관이 참여하 는 전수조사에 비해 결코 적지 않았으며, 전수감시체계 초기인 2011년, 2012년, 2013년도에 보고된 환자 수는 1차 표본감 시 때보다 적었다. 이는 2020 년도의 같은 표본감시체계 하에 보고된 환자 수와 비교하면 뚜렷한 차이가 관찰되었다. 본 연구 결과와 같이 1 차 전수감시체계 기간 동안 환자 감소 현상은 전수감시체계가 시작된 2011년도부터 우리나라 매독 환자의 급격한 감소 가능성을 생각할 수 있다. 그러나 저자들이 구한 우리나라 건강보험심사평가원 자료에 따르면 2008년도 부터 2014년까지 조기 매독 환자 수는 일정하였으며, 이들을 대상으로 일선 의료기관으로부터 의료비 청구가 이루어짐을 
고려한다면, 그 기간 동안 환자의 급격한 감소보다는 다른 가능성을 고려하여야 할 것이다. 1 차 표본감시체계 자료에 여성이 남성보다 많았으며 이는 1 차 전수감시체계와 비교해 통계적으로 뚜렷한 차이를 보여주었다. 1기, 2기 매독의 성별 차이는 전 세계에서 공통으로 남성이 여성보다 많이 발생하는 것으로 알려졌으며, 2008년도에서 2014년도까지 조사한 우 리나라 건강보험심사평가원 자료 분석에도 모든 연도에서 남성 우위 현상이 일관되게 관찰되었다[7,12,15].

이에 저자들은 1 차 표본감시체계에서 보고된 자료를 상세 히 검토하기 위해 2001년부터 2016년 9월까지 의료기관별 매독 보고 건수 자료를 우리나라 질병관리청으로부터 받아 분석하였다. 1 차 표본감시체계에 참여해 매독 환자를 보고한 의료기관 수는 연평균 $94.4 \pm 32.63$ 개였으며, 한 의료기관당 1 년 동안 평균 보고 건수는 $3.99 \pm 1.01$ 건이었다. 반면에 2016년까지 6년간 1차 전수조사체계 시기에 참여해 조기 매독 환자를 보고한 의료기관 개수는 1 년 평균 $206.5 \pm 43.80$ 개였으며, 그 평균 보고 건수는 1 년에 $2.60 \pm 0.14$ 건이었다. 두 보고체계에 참여한 의료기관의 수는 전수감시체계 때가 많았으나, 보고 건수는 1차 표본감시체계 때가 더 많았다.

Supplement Table 1 분석에 포함된 의료기관은 2001년 에서 2016년 동안 매독 환자를 많이, 그리고 꾸준히 보고하였 던 일부 의료기관들이다. 요양기관 번호는 16년 동안 기관별 보고 수를 추정하기 위해 연구자가 임의로 부여하였다. pre6 는 2005년부터 2010년까지 6년간 1차 표본감시체계 동안 보고된 조기 매독 환자 수의 합이며, post6은 2011년부터 2016년 9월까지 6년간 1차 전수보고체계 시기 동안 보고된 매독 환자 수다. 1 차 표본감시체계 기간 동안 다량으로 매독 환자를 보고한 소수 의료기관의 보고 환자 수가 1 차 전수보고 체계 기간에는 대부분 큰 폭으로 감소하였다. 1 차 전수감시체 계 기간에도 적은 수의 환자를 꾸준히 보고하는 의료기관이 있었으나, 보고 수는 1 차 표본조사에 비해 적었다.

조기 매독이 페니실린이라는 특효약으로 완치가 잘되고 진단 또한 표준화되어 있어, 조기 매독 환자가 소수 의료기관에 집중될 이유가 없으며, 본 연구에서 보여주는 것과 같이 감시체 계의 개정에 따른 환자 수의 급격한 변화, 그리고 매독의 특징 인 성별의 차이점 등을 종합해 보면 매독 환자에 대한 1차 전수감시체계의 결과가 1 차 표본감시체계의 결과보다 우수한 것으로 생각한다. 1 차 표본감시체계 결과에 대해 생각할 수 있는 오류는 여성이 많은 산부인과 위주로 감시체계를 설계하 였거나, 남성 매독 환자를 많이 진단하는 비뇨의학과의 보고 누락, 의료 당사자들의 매독에 대한 교육 부족이나 비매독항원 시험법만을 이용한 매독 진단 혹은 보고, 그리고 국가의 수동적 감시체계로 인한 무관심 등에서 기인한 것으로 추정된다[9].

Fig. 2 에서 1 차 표본감시체계 때나 1 차 전수감시체계의 결과에 따르면 동일하게 20-29세에서 조기 매독이 가장 빈발
하게 보고되었다. 이는 전 세계적인 현상으로 가임기의 여성이 나 그 시기의 성배우자인 남성에게 매우 중요한 질병임을 암시하고 있다[13-15,18]. 흥미로운 것은 두 감시체계 모두 시간이 지나감에 따라 20-29세의 빈도수 증가가 더욱더 도드 라졌으며, 이는 매독 환자의 유병률 변화를 의미하는 것인지 아니면 기존 보고체계가 안정화 단계에 도달함을 의미하는 것인지 확실하게 알 수는 없었다. 1 차 표본감시의 결과는 1 차 전수감시의 결과와 비교해 장년층에서 상대적으로 높은 발생 빈도를 보여준다(Fig. 2). 이는 장년층의 매독이 높은 발생을 추정할 수 있으나, 그 후 시행된 전수조사 결과를 고려 한다면 잘못된 보고일 가능성 또한 고려하여야 한다. 이를 뒷받침하는 연구로는 무증상 매독을 보고 체계에 넣어 관리하 는 일본 보고가 있는데, 일본의 20-29세의 높은 매독 보고와 이들이 일부 장년층으로 감염이 이어져 만성으로 진행된 환자 로 보고된다는 점을 고려한다면(Fig. 4), 우리나라의 1차 표본 감시의 결과 중 40-59세의 매독 감염 빈도가 상대적인 높음은 아마도 그들 중 일부는 만기 매독도 포함되어 신고되었을 가능성도 생각해야 한다.

1차 전수감시체계를 통해 얻은 2011년-2015년도까지 5개 년 각각의 연령 분포는 서로 비슷해 한 개의 군집을 이루고, 2016년도-2019년도까지 4개년도 연령 분포 또한 또 다른 군집을 이루는데, 이는 20-29세 환자 발생이 2016년도부터 급격히 증가해 2017, 2018년도를 거쳐 정점을 찍은 후 2019 년도에 감소하는 특징을 보여주고 있다. 이는 일본 후생성 자료에서도 유사하게 관찰되고 있다(Fig. 2-4). 지난 5년 동안 일본 사회에서는 매독 환자 증가가 큰 사회 문제가 되고 있었다 [20,21]. 이러한 점을 고려해 본다면, 우리나라에서도 관찰되 는 2015년도부터 시작된 20-29세의 환자 증가의 특징적 소견은 우리나라 의료계가 매독 발생에 대해 앞으로 지속적인 관심 및 추적 조사가 필요할 것으로 생각한다. 또한 양국 모두 일관되게 관찰되는 현상, 즉 2018년도보다 2019년도의 20-29세의 빈도수 감소 소견이 매독 확산 억제의 전환점인지 는 혹은 일시적인 현상인지는 향후 지속적인 연구가 필요하다.

2020년도 시행되었던 매독 2차 표본감시체계의 결과, 즉 환자의 연령 분포나 성별 결과를 1 차 전수감시체계의 결과와 비교해 보면 합리적으로 생각되며, 이는 과거 1차 표본감시체 계의 결과와 크게 다름을 알 수 있었지만, 2 차 표본감시체계의 유용성을 판단하기 위해서는 향후 장기간의 관찰 결과가 필요 하다.

\section{결론}

매독은 현재에도 지속해서 관찰되고 있는 감염병으로 매독 자체뿐만 아니라 후천성면역결핍증과의 관련성, 여성 보건에 미치는 영향력, 태아에 끼치는 심각한 영향을 고려한다면 감시 
체계 유지는 매우 중요하다. 그러나 우리나라에서 20년 동안 3 번 개정된 매독의 보고체계를 분석해 보면 전수감시체계 혹은 표본감시체계의 시스템이 중요한 것이 아니라, 보고체계 에 관여한 모든 사람의 지속적인 관심 특히 보건당국의 지원과 결과 공개, 의학계의 지속적인 교육, 그리고 보고 당사자의 적극적인 참여와 의학적 지식 습득이 중요하다고 할 수 있다. 그리고 2020년도 시작된 매독의 감시체계 평가는 1개 연도 자료로 정확한 평가가 이루어질 수 없지만, 2011년-2019년 도까지 시행된 결과로 미루어볼 때 1차 표본감시체계보다는 합리적이라 평가된다. 그러나 모자보건에 중요한 척도인 선천 성 매독의 보고 건수가 매우 적어 향후 보완이 필요할 것으로 생각한다.

\section{CONFLICT OF INTEREST}

No potential conflict of interest relevant to this article was reported.

\section{ACKNOWLEDGMENTS}

We are grateful to the officials of the medical institutions, public health centers, and the Division of Infectious Disease Control, Korea Disease Control and Prevention Agency, who provided the data used for statistical analysis.

\section{AUTHOR CONTRIBUTIONS}

Y.S. and G.L. participated in data collection and study design, performed the statistical analysis, and wrote the manuscript. All authors read and approved the final manuscript.

\section{ORCID}

Yumi Seo, http://orcid.org/0000-0001-8027-7170

Gilho Lee, http://orcid.org/0000-0002-9253-6245

\section{SUPPLEMENTARY MATERIAL}

Supplementary data can be found via https://doi. org/10.14777/uti.2021.16.1.16.

\section{REFERENCES}

1. World Health Organization (WHO). WHO coronavirus (COVID-19) dashboard [Internet]. Geneva: WHO c2021 [cited 2021 Jan 10]. Available from: https://covid19.who.int.

2. Mohammed H, Hughes G, Fenton KA. Surveillance systems for sexually transmitted infections: a global review. Curr Opin Infect Dis 2016;29:64-9.

3. Taniguchi K, Hashimoto S, Kawado M, Murakami Y, Izumida M, Ohta $A$, et al. Overview of infectious disease surveillance system in Japan, 1999-2005. J Epidemiol 2007;17(Suppl):S313.

4. Park S, Cho E. National infectious diseases surveillance data of South Korea. Epidemiol Health 2014;36:e2014030.

5. Thacker SB, Berkelman RL. Public health surveillance in the United States. Epidemiol Rev 1988;10:164-90.

6. Berman SM, Ellen JM. Adolescents and STDs, including HIV infection. In: Holmes KK, Sparling PF, Stamm WE, Piot P, Wasserheit JN, Corey L, et al., editors. Sexually transmitted diseases. 4th ed. New York: McGraw-Hill 2008. p. 165-85.

7. Sparling PF, Swartz MN, Musher DM, Healy BP. Clinical manifestations of syphilis. In: Holmes KK, Sparling PF, Stamm WE, Piot P, Wasserheit JN, Corey L, et al., editors. Sexually transmitted diseases. 4th ed. New York: McGraw-Hill; 2008. p. 661-84.

8. Korea Disease Control and Prevention Agency (KDCA). KDCA new classification for legal communicable disease in Korea[Internet]. Cheongju: KDCA c2019 [cited 2021 Jan 10]. Available from: http://kdca.go.kr/contents.es?mid=a21110000000.

9. Lee GH. The current surveillance system for sexually transmitted diseases in Korea and plans for its improvement [Internet]. Sejong: Ministry of Health and Welfare c2017 [cited 2020 Jan 10]. Available from: http://www.prism.go.kr/home page/lately/retrieveLatelyDetail.do;jsessionid $=64$ F502EBF82 6EBD137216369710C711B.node02? research_id=1351000-2 01600272.

10. Korea Disease Control and Prevention Agency (KDCA). KDCA Infectious disease portal [Internet]. Cheongju: KDCA [cited 2020 Jan 10]. Available from: http://www.kdca.go.kr/npt/ biz/npp/ist/simple/simplePdStatsMain.do.

11. Korea Disease Control and Prevention Agency (KDCA). Infectious diseases surveillance yearbook, 2019 [Internet]. Cheongju: KDCA c2020 [cited 2020 Dec 20]. Available from: http://www.kdca.go.kr/npt/biz/npp/portal/nppPblctDtaView.d o?pblctDtaSeAt $=1$ \&pblctDtaSn $=2139$.

12. Ministry of Health, Labour and Welfare. Number of reported sexually transmitted diseases [Internet]. Tokyo: Ministry of Health, Labour and Welfare [cited 2020 Dec 20]. Available from: https://www.mhlw.go.jp/topics/2005/04/tp0411-1.html.

13. World Health Organization (WHO). A tool for strengthening STI surveillance at the country level [Internet]. Geneva: WHO 
c2015 [cited 2020 Dec 20]. Available from: https://www.who. int/reproductivehealth/publications/rtis/sti-surveillance/en.

14. Haldar P, Morineau G, Das A, Mehendale S. A surveillance model for sexually transmitted infections in India. Indian J Public Health 2015;59:286-94.

15. Centers for Disease Control and Prevention (CDC). Sexually transmitted disease surveillance 2018 [Internet]. Atlanta: CDC c2019 [cited 2020 Dec 20]. Available from: https://www.cdc. gov/std/stats18/default.htm.

16. Lee G (Department of Urology, Dankook University, Cheonan, MD). Conversation with: Donghan Lee (Surveillance Department, Korea Disease Control and Prevention Agency, Osong). 2016 May 5.

17. Peeling RW, Mabey D, Kamb ML, Chen XS, Radolf JD, Benzaken AS. Syphilis. Nat Rev Dis Primers 2017;3:17073.

18. World Health Organization (WHO). Methods for surveillance and monitoring of congenital syphilis elimination within existing systems [Internet]. Geneva: WHO c2011 [cited 2021 Jan 10]. Available from: https://www.who.int/reproductive health/publications/rtis/9789241503020/en.

19. Park IU, Tran A, Pereira L, Fakile Y. Sensitivity and specificity of treponemal-specific tests for the diagnosis of syphilis. Clin Infect Dis 2020;71(Supplement_1):S13-20.

20. Sugishita Y, Kayebeta A, Soejima K, YauchiM. Rapid increase of syphilis in Tokyo: an analysis of infectious disease surveillance data from 2007 to 2016. Western Pac Surveill Response J 2019;10:6-14

21. Echigoya $Y$, Yamaguchi T, Imamura A, Nishiura H. Estimating the syphilis incidence and diagnosis rate in Japan: a mathematical modelling study. Sex Transm Infect 2020; 96:516-20. 